\title{
Contribution of non-timber forest products to the livelihood of farmers in coffee growing areas: evidence from Yayu Coffee Forest Biosphere Reserve
}

Article

Accepted Version

Beyene, A. D., Mekonnen, A., Hirons, M., Robinson, E. J. Z., Gonfa, T., Gole, T. W. and Demissie, S. (2020) Contribution of non-timber forest products to the livelihood of farmers in coffee growing areas: evidence from Yayu Coffee Forest Biosphere Reserve. Journal of Environmental Planning and Management, 63 (9). pp. 1633-1654. ISSN 1360-0559 doi:

https://doi.org/10.1080/09640568.2019.1679615 Available at https://centaur.reading.ac.uk/87263/

It is advisable to refer to the publisher's version if you intend to cite from the work. See Guidance on citing.

To link to this article DOI: http://dx.doi.org/10.1080/09640568.2019.1679615

Publisher: Taylor \& Francis

All outputs in CentAUR are protected by Intellectual Property Rights law, including copyright law. Copyright and IPR is retained by the creators or other copyright holders. Terms and conditions for use of this material are defined in the End User Agreement. 


\section{www.reading.ac.uk/centaur}

\section{CentAUR}

Central Archive at the University of Reading

Reading's research outputs online 


\title{
Contribution of non-timber forest products to the livelihood offarmersin coffee growing areas: Evidence from Yayu Coffee Forest Biosphere Reserve
}

\author{
Abebe D. Beyene ${ }^{1}$, Alemu Mekonnen ${ }^{2}$, Mark Hirons ${ }^{3}$, Elizabeth J.Z. Robinson ${ }^{4}$, \\ Techane Gonfa ${ }^{5}$, Tadesse W. Gole ${ }^{6}$, Sheleme Demissie ${ }^{7}$ \\ ${ }^{1}$ Environment and Climate Research Center (ECRC), Ethiopian Development Research Institute (EDRI), Addis \\ Ababa, Ethiopia, Email: abebed2002@yahoo.co.uk \\ ${ }^{2}$ Department of Economics, Addis Ababa University, Ethiopia, Email: alemu_m2004@yahoo.com \\ ${ }^{3}$ Environmental Social Science Research Fellow, Environmental Change Institute, Oxford University Centre for the \\ Environment, Email:mark.hirons@ ouce.ox.ac.uk \\ ${ }^{4}$ Professor of Environmental Economics, School of Agriculture, Policy and Development, University of Reading, \\ Email: e.j.robinson@ reading.ac.uk. \\ ${ }^{5}$ Environment, Climate Change and Coffee Forest Forum (ECCCFF),Email: nateabe2004@ gmail.com \\ ${ }^{6}$ Environment, Climate Change and Coffee Forest Forum (ECCCFF),Email: twgole@gmail.com \\ ${ }^{7}$ Environment, Climate Change and Coffee Forest Forum (ECCCFF),Email: shelemede06@gmail.com
}

\begin{abstract}
This paper examines the role of forest products in the livelihoods of forest-dependent households in the Yayu Coffee Forest Biosphere Reserve in the South Western part of Ethiopia. Unlike many forest landscapes, households in Yayu district cultivate their primary crop, coffee, in a complex landscape. Sampled households $(\mathrm{n}=241)$ were chosen based on stratified random sampling method. We employ both descriptive statistics and econometric regression to assess the extent of forest products use and analyse the determinants of forest income, respectively. We find that relatively poor households are more dependent on forests resources as a share of total income than better off households. We further find that households in Yayu district use non-timber forest products (NTFPs) mainly for consumption. The current zoning arrangements around the Biosphere reserve support the provision of NTFPs, particularly for poorer households and should be considered for replication in other complex landscapes.
\end{abstract}

Key words:Forest income; Livelihoods; Dependence; NTFPs; Rural Ethiopia

JEL Classification:Q23, L73 


\section{Introduction}

More than 1.6 billion people in the world rely on forests for their livelihood (Chao 2012) and more than a quarter of a billion people live in or around the dry forests of sub-Saharan Africa (CIFOR 2008). Most depend directly on the forests for timber products such as building materials and nontimber forest products (NTFPs ${ }^{1}$ ) such as firewood, wild fruits, medicinal plants, spices, and fodder, which may be consumed by the household or sold for cash income. Forests can increase the resilience of communities further by serving as economic safety nets in critical periods (FAO 2016). The dependence of poor people on natural resources for survival can lead to the depletion of resources, exacerbating environmental stress, or can provide incentives to manage these resources sustainably (Robinson 2016). Thus understanding the role that forests play in the livelihoods of the local people surrounding the biosphere is an important step in improving the long-term management of forests for the benefit of people and the environment.

Ethiopia's Yayu Coffee Forest Biosphere Reserve (YCFBR) is the center of origin of Coffea Arabica, the most popular coffee in the world. The forest is also one of the National Forest Priority Areas (NFPA), mainly for conservation of biodiversity and coffee genetic resources, for which a part of the forest has also been designated since 1998. Households, many of them poor, live in and around the biosphere reserve, yet how these households interact with the biosphere reserve, particularly with regards to coffee production and the collection of NTFPs, remains insufficiently understood. Additional information on the NTFP- livelihood nexus in this kind of biosphere with a complex landscape can serve as an input for stakeholders aiming for the sustainable management of the biosphere. It is therefore timely and important to examine the forest- poverty nexus by exploring the contribution of the biosphere reserve to people's livelihood.

Many studies have recognized and quantified the importance of forest and environmental resources to rural household income in lower-income countries. Available empirical studies from Africa and Asia show that forest income contributes between $10 \%$ and $60 \%$ of income for households living in forest landscapes (Cavendish 2000; Fisher 2004; Mamo et al. 2007; Kamanga et al. 2009; Heubach et al. 2011). For example, Heubach et al. (2011) found that, on average, income from NTFPs accounted for 39\% of total household income and had a strong equalizing effect. Households in Malawi derive about 15-30\% of their income from forests (Fisher 2004; Kamanga et al. 2009). Similarly, Cavendish (2000) found that environmental goods are significant 
source of total income in Zimbabwe, with $35 \%$ of total income derived from these goods. Literature from Ethiopia similarly indicates that forest products play a significant role in the livelihood of rural people. For example, Mamo et al. (2007) found that total income from Chilmo participatory forest management (PFM), Ethiopia, contributed up to $40 \%$ of total household income. Babulo et al.(2009) found that forest products contribute between 22 to $35 \%$ of the total income of households in northern Ethiopia. Beyene and Koch (2011) find that a sample of households in the south western part of Ethiopia derive on average 8.7\% of their total income from non-wood (i.e. excluding wood fuels) forest products (NWFPs). They further demonstrate that the quantity of forest products and thus income derived from forests depends on the type of forest management. Asfaw et al. (2013) find that forest income contributes more than $32 \%$ of total income of respondents in Jelo forest in eastern Ethiopia.

The economic importance of NTFPs differs between households. Poorer households have been found to be relatively more dependent on NTFPs in order to fulfill basic needs than wealthier households (Cavendish 2000; Tesfaye et al. 2010; Heubach et al. 2011; Kar and Jacobson 2012; Asfaw et al. 2013). However, the latter are typically found to extract more NTFPs in absolute terms and have significantly higher cash returns from forest products than poorer households. This is variously due to higher-income households having large numbers of livestock and thus a greater need to collect fodder (Cavendish 2000), better harvesting equipment, greater access to markets, and better connection to trade infrastructure (Arnold and Perez 2001; Angelsen and Wunder 2003) in addition to having greater land holdings from which they can also gather NTFPs (Heubach et al. 2011).In their analysis of the relationship between household characteristics and forest dependency in Nepal, Adhikari et al. (2004) found that household wealth indicators such as land and livestock holdings exert a strong influence on appropriating benefits from the commons. On the other hand, forest dependence is inversely related with area of cropland and number of large livestock (Tesfaye et al. 2010). A number of socioeconomics characteristics such as household size (e.g. Adhikari et al. 2004; Kamanga et al. 2009; Cordova et al. 2013) positively affect forest resource use. Location of households may also influence forest dependency. Studies argue that forest products are important in rural incomes for households residing in remote villages where there is lack of infrastructure (Tesfaye et al. 2010; Cordova et al. 2013). Similarly, those located far from the forest derive more resources such as fire wood in Nepal (Adhikari et al. 2004). Neumann and Hirsch (2000) noted that the contribution of NTFPs to households can be highly 
differentiated by gender, class and ethnicity. For example, the availability of more female members in a household reduces the likelihood of participation in NTFP activities in India (Dash et al. 2016).Similarly, Asfaw et al.(2013) in Ethiopia show that forest resources are more important for female headed households than male headed households. Education increases the opportunity cost of spending time collecting forest resource as it enhances other employment opportunities and has been found to reduce both absolute and relative forest income (Kamanga et al. 2009). Scholars also discuss the role of access to credit in forest resource extraction. For example, Babulo et al.(2009) argue that credit enables local people to look for better business opportunities instead of relying on forest resources.

Despite the growing literature on the forest poverty nexus, knowledge of the dependence of communities on nearby forests and factors affecting this dependence, particularly in complex landscapes, is still limited. Furthermore, the contribution of forest resources to the livelihoods of rural people varies across studies depending on the nature of forest products included in the study, methods employed in the valuation of products, and the type and management of forests prevailing in the study area. In general, it is difficult to generalize about the role of forest income in the livelihood of rural people due to differences in methodology and bias in the study location (Angelsen et al. 2014).

Therefore, this study aims to test the following hypotheses. The first hypothesis is that households' dependency on forest resources, i.e. the share of income derived from forest resources, declines as their income increases. ${ }^{2}$ The second hypothesis is that the relationship between the gross value of forest products collected and total income or better asset ownership is expected to be positive in the current study area where there is a complex landscape. That means, we investigate and test whether the better off households extract more resources from the forest, though small relative to their total income. In addition, we will assess the role of forest resources in the overall livelihood of the people in terms of satisfying their cash and subsistence requirements.

Our research contributes to the literature in a number of ways. First, the research contributes to the broader understanding of the role of NTFPs in rural livelihoods. Second, in contrast to much of the literature, we focus on a forest landscape in which the boundaries between 
agriculture and forest are blurred. In this landscape most farmers cultivate coffee, their most important cash crop, in semi-forested areas, in the reserve buffer zone, located between a highlyprotected core and a less forested transition zone. Third, we quantify the contribution of forest ecosystems to the livelihood of the local people in this complex landscape where coffee growing is the most important activity. Empirical studies such as ours remain important because the link between forests and poverty tends to be site specific (Kar and Jacobson 2012).

The paper is organized in the following way. In Section 2 we present materials and methods. In Section 3, we present results and discussions. Section 4 present conclusions and policy implications.

2. Materials and methods

\subsection{Description of the study area}

Yayu district is located in the southwestern part of the country in Oromiya region. It is $520 \mathrm{~km}$ from Addis Ababa, the capital city of Ethiopia. The YCFBR encompasses six districts of Ilu Abba Bora Zone, namely Hurumu, Yayu, Chora, Nopha, AlgeSachi and Doreni. The YCFBR is located within $8^{\circ} 0$ ' $42^{\prime \prime}$ to $8^{\circ} 44^{\prime} 23^{\prime \prime} \mathrm{N}$ and $35^{\circ} 20^{\prime} 31^{\prime \prime}$ to $36^{\circ} 18^{\prime} 20^{\prime \prime}$. The mean minimum and maximum temperatures in the area is $12.7^{\circ} \mathrm{C}$ and $26.1^{\circ} \mathrm{C}$, respectively, and mean annual rainfall is $2,100 \mathrm{~mm}$.

The YCFBR was registered in 2010 as one of the United Nations Educational, Scientific, and Cultural Organization's (UNESCO) sites for its significant role in the conservation of natural and cultural landscapes. The YCFBR became one of the NFPAs for forest conservation in the 1980s and covers around 150,000 ha (Gole et al. 2009). It is the largest and most important forest for the conservation of the wild populations in the world. ${ }^{3}$ The area is also known for its cultural and historical significance since it possesses many archaeological and ritual sites. ${ }^{4}$

Similar to other parts of the country, agriculture in Yayu area is characterized by smallholder subsistence farming with low productivity (Gole et al. 2009). Local people practice

expansion of cultivated land by removing trees at the expense of forest areas, which can drive deforestation (Gole et al. 2009). However, the annual deforestation rate in the YCFBR is $0.25 \%$ 
(Beyene 2014) considerably lower than the national annual deforestation rate of $1.1 \%$ for the period 2005-2010(FAO 2010) due to less intensive use of the land in the core areas (Beyene 2014). The NFPA allows the local communities to extract non-timber forest products like wild coffee, honey, spices and others without practicing any management interventions. Figure 1 shows the zonation of YCFBR.

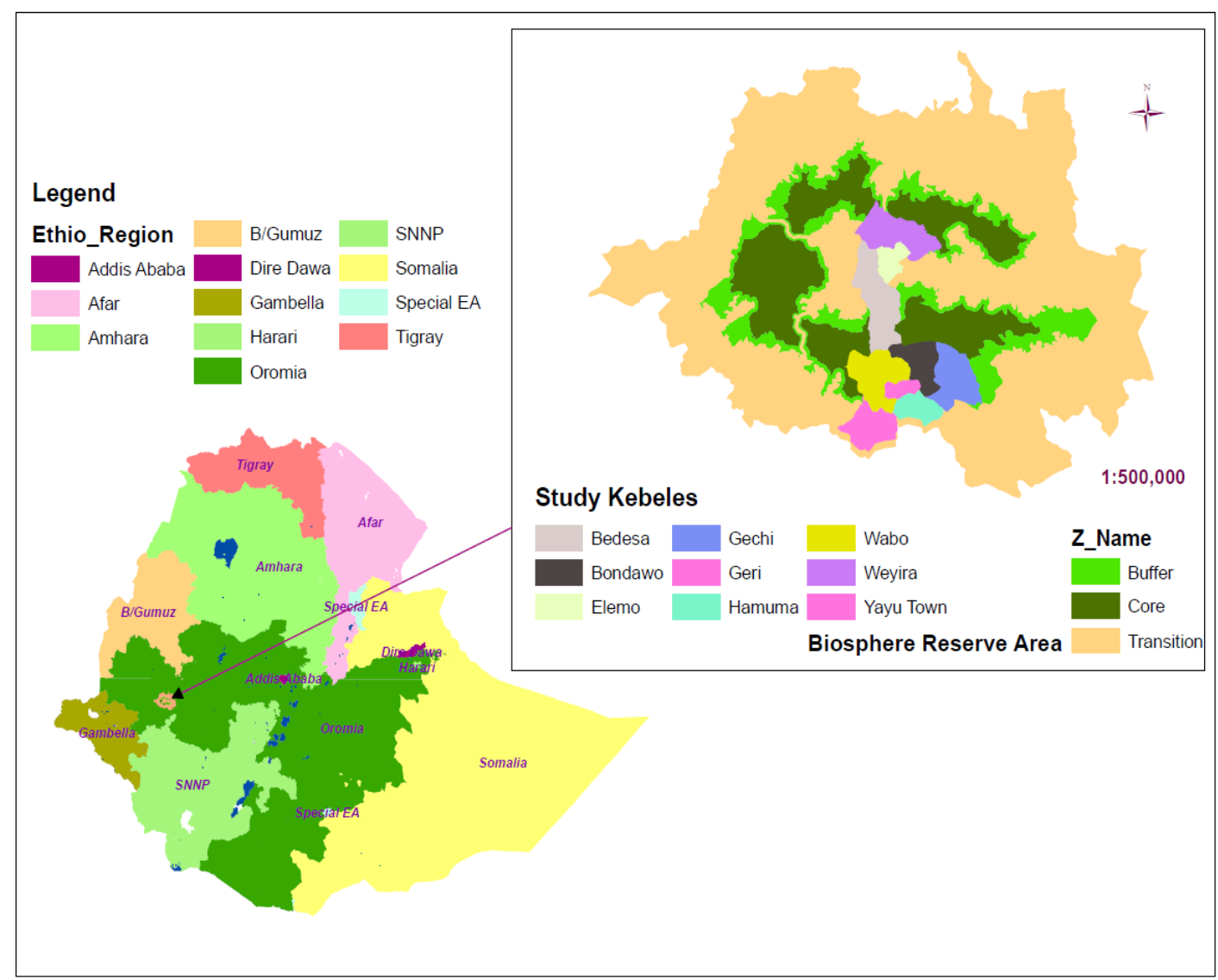

Source: Authors

Figure 1. Zonation of Yayu Coffee Forest Biosphere Reserve

The YCFBR has a total area of 167,021 ha and has three different management zones, namely: core area, buffer zone, and transition area (Gole et al. 2009). Core areas are protected sites with high abundance of wild populations of Arabica coffee and high species diversity. The local communities are not supposed to take anything from these areas, which are designated for nondestructive research and monitoring purposes only. Thus the core areas, just under 28,000 hectares, represent relatively intact forest of high conservation value for coffee and forest biodiversity (Gole 
et al. 2009). The buffer zones are located next to the core area, and are forest areas managed by members of the local community for coffee and non-timber forest products such as spices and honey production in the form of semi-forest coffee systems. This area also serves as a connection between the core and transition zones. Farmers traditionally claim some area of land in the buffer zone and are allowed to collect forest products from this area as well as cultivating coffee. More than $70 \%$ of the YCFBR is covered by the transition zone (Gole et al. 2009). In this area people undertake various activities such as growing crops, grazing livestock, and cultivating coffee home gardens, while some areas are settlement areas. The major objective in the transition zone is to achieve sustainable resource use by involving all the relevant stakeholders.

\subsection{Sampling and data collection}

Data were collected from a sample of households in two districts of the YCFBR, namely Yayu and Doreni. A total of ten kebeles, ${ }^{5}$ three from Doreni district and seven from Yayu district, were chosen. Kebeles within districts were selected randomly. We used stratified proportional random sampling method that accounted for gender and three wealth levels. We used wealth and gender as the main criteria in order to enhance the representativeness of our sample. In addition, wealth is one of the main variables that has been shown to have a significant effect on collection of forest resources. Six categories: poor (male and female headed households), medium (male and female), and rich (male and female) were considered. Wealth of kebele members was discretely identified by the kebele committees. The kebele committees ranked the wealth of their members based on their experience. Since they are living in the same areas, the committees know who is relatively poor or rich in the locality and were able to categorize each household as poor, medium, and rich. We recognize that this is a somewhat subjective way to stratify the sample, but given the logistical constraints (i.e. the impossibility of a census-style pre-survey study) it was felt to be most appropriate for the study. Then the total number of sample households in a kebele was determined proportionately. For the purpose of selecting sampled households, the sampling frame was based on the registration of households and their farms with kebeles, but interviews were conducted in each household's home. A total of 161 households were selected using a random number generator. The remaining 80 households were selected for ecological monitoring on farms as part 
of a wider ecosystem services and poverty alleviation (ESPA) project (ecolimits.org). These 80 respondents, with whom plots for ecological monitoring were established, were randomly sampled based on a spatial-ecological stratification of elevation, connectedness to forest (patch size) and shade level on the farm. 175 households (72.6\%) were chosen from Yayu district and the remaining 66 households (27.4\%) were selected from Doreni district. The questionnaire was prepared first in English, and then translated to Afan Oromo, the local language in the study area. Field enumerators were chosen based on their experience and fluency in speaking the local language. They were trained for two days. Face-to-face interviews were conducted and took, on average, 3 hours per household. The field survey was conducted with close supervision of some of the coauthors of this paper.

The survey questionnaire mainly focused on questions related to forest resource use from the YCFBR and forest management activities. Other information collected included household demographics, land issues such as farm size and ownership, and agricultural production. The interviews were conducted from February 8, 2015 to February 18, 2015. We employed survey software known as open data kit (ODK), an android based open-source software for survey work. We transferred the data to the statistical software package Stata version 14.

\subsection{Methods of valuation of forest products and measurement issues}

Valuing forest products is a difficult exercise due to the non-tradability of some of the forest products and due to the seasonality of many forest products (Robinson 2016). Some studies use an opportunity cost method. For example, Cooke (1998) considered the time taken to collect a unit of a forest product multiplied by the market wage rate. Other studies used the barter system (e.g. Adhikari 2005) which requires asking the participants to discuss within their group about the quantity of a local commodity, which has well known market value, they deserve in exchange for a unit of a forest product.

In this study, information about production, consumption and sale of various forest

products was obtained from each household. Some forest products such as fuel wood, wild coffee, honey, and spices are traded in local markets. Other forest products such as fodder do not have a market price in the study area and are mainly used for subsistence. We used different approaches 
to value the forest products. In the first approach, we estimate the value of tradable products by taking the products of quantities collected and local market price (an approach used by Fisher 2004; Mamo et al. 2007). We obtained a list of prices for various agricultural and forest products from the local Trade and Market Development Office. For some products which have prices in the market but are not uniform, such as spices, we took the average price of a unit bundle of different spices including, for example, ginger and cardamom (Korerima), to value the product, and multiplied by the number of units collected by the households. We adopted the same strategy to value other bundles of related NTFPs.

For other products, such as liana which is seasonally available in the market and does not have a specific market area, we took three samples from the different entry points to the town and asked farmers how much they would be willing to pay if they were to purchase a unit of that particular product from the $\operatorname{market}^{5}$ (see for example, Lopez-Feldman et al. 2007). Farmers' responses were used to calculate the total value of liana collected by each household. Research assistants weighed the different products and these were used to convert local units of weight measurement reported by respondents to standard units.

Some forest products in the study area do not have a market at all. Households only collect them for own consumption. For example, medicinal plants are collected almost exclusively by traditional healers for preparing different kinds of medicines for curing various types of ailment with, for example, cancer and gastritis. It is not common for local people (not involved in traditional healing) to collect the medicinal plants as they do not know how to use them. It is also very difficult to obtain full information about these plants as the traditional healers are afraid of people imitating their skills. Respondents were asked to report the weight of the medicine collected. In cases where local measurement units are used the researchers measured the weight of the medicine using a weighing scale and converted it into standard units. Three samples were taken from three traditional healers and the average values (both the conversion and price) were considered to value the medicinal plants. Unlike liana, the measurement and conversion was done while the interviewers were with the respondents in or around the latter's houses. Field workers clearly explained the purpose of the study to the respondents and then asked for their consent before proceeding to the interview. 
Information about non-timber forest products was asked for the previous twelve months. The frequency of collection varies, with some products collected every week or twice a month or once a month. Some forest products are seasonally available. The enumerators were trained to convert data in to the equivalent per annum. Finally, using the various approaches we imputed the total income-equivalent value obtained from non-timber forest products. ${ }^{6}$

\subsection{Empirical strategy}

The dependent variables are the total value of non-timber forest products collected and forest dependency, which is measured as the share of imputed/actual income obtained from non-timber forest resources to household's total income. The explanatory variables are various household and community level variables. Our data show that not all households collect all types of forest products, implying that forest resource use is censored at zero. Thus, we use Tobit models to analyze factors associated with the value of NTFPs collected as well as forest dependency. ${ }^{8}$

$$
\begin{aligned}
& Y_{t}=X_{t} \beta+\varepsilon_{t} \text { if } X_{t} \beta+\varepsilon_{t}>0 \\
& =0 \text { if } X_{t} \beta+\varepsilon_{t} \leq 0 \text { where } t=1,2,3, \ldots \ldots \ldots ., N
\end{aligned}
$$

Where $t$ represents the observation and $N$ is the number of observations, $Y_{t}$ is the dependent variable, $X_{t}$ is a vector of explanatory variables, $\beta$ is a vector of unknown coefficients, and $\varepsilon_{t}$ is an independently distributed error term assumed to be normal with zero mean and constant variance, $\sigma^{2}$. In order to reduce the problem of heteroscedasticity some of the variables were transformed in to logarithmic form. In addition, appropriate computations of heteroscedasticity consistent standard errors were employed in all the regressions (White 1980). We tested for multicollinearity which was found not to be a serious problem. The VIF was 10 and below for all variables. When we omit one of the relatively collinear variables, i.e., distance to nearest road and district dummy, the overall result remained the same. We first estimate the determinants of the gross value of nontimber forest products collected. Second, we examine the factors that determine the share of income derived from NTFPs. We also run separate regressions for some major NTFPs in the study area. The choice of specific variables depends on the type of forest product, the nature of the available data, the socioeconomic and ecological context, and the objectives of the study. Explanatory variables included in the empirical analysis are selected based on the empirical 
literature on forest poverty nexus (see for example, Sills et al. 2003; Adhikari et al. 2004; Kamanga et al. 2009).

\section{Results and Discussions}

\subsection{Summary of descriptive statistics}

Table 1 presents the descriptive statistics of the variables used in the analysis. The table shows that respondents in the sample are, on average, 44 years old and $85 \%$ are male. In the literature, the effect of age on forest dependence is mixed (see for example, Cavendish 2000). Close to $84 \%$ of the respondents are married. Education level of the household head was measured by asking the respondent the number of years of schooling completed. Education increases the opportunity cost of time spent for collection of forest resources and so may reduce dependence on forest resources (Mamo et al. 2007). Close to 36\% have no formal education while the remaining $64 \%$ have attended formal education with an average grade of 4.1 years of schooling. In terms of asset ownership, we have considered the number of livestock owned by the household. It is measured by converting each type of livestock into its tropical livestock unit (TLU) equivalent. The average number of livestock owned is 2.10TLU. On average, farm households have 1.19 hectares of land for coffee growing. Based on the literature, we might anticipate that households who are relatively better in terms of asset/wealth indicators (i.e. number of livestock owned, area of land allocated for coffee) and monthly household expenditure have a lower dependency on forest resources. However, we expect that the relationship between the gross value of forest products collected and income or better asset ownership to be positive. 
Table 1. Descriptive statistics of selected variables

\begin{tabular}{|c|c|c|c|c|}
\hline Description of Variables & Mean & Std. Dev. & Min & Max \\
\hline Age of respondent & 44.45 & 15.92 & 18 & 90 \\
\hline Gender of respondent ( 1 if male) $(\%)$ & 85 & & & \\
\hline Marital Status (1 if married, 0 otherwise) $(\%)$ & 84 & & & \\
\hline Education of respondent (years completed) & 4.10 & 4.09 & 0 & 14 \\
\hline Presence of children under $5(\%)$ & 38 & & & \\
\hline Number of other adults above 18 years & 1.17 & 1.81 & 0 & 16 \\
\hline Access to credit ( 1 if has access, and 0 otherwise) $(\%)$ & 70 & & & \\
\hline Number of livestock in TLU & 2.10 & 2.22 & 0 & 9.8 \\
\hline Coffee area in $\mathrm{Ha}$ & 1.19 & 1.17 & 0 & 6 \\
\hline Household monthly expenditure in Birr & 902.15 & 712.43 & 93.33 & 4595 \\
\hline $\begin{array}{l}\text { Health status ( } 1 \text { if poor health frequently affects } \\
\text { household, } 0 \text { otherwise }(\%)\end{array}$ & 38 & & & \\
\hline $\begin{array}{l}\text { Household's most important activity ( } 1 \text { if it is coffee } \\
\text { farming, } 0 \text { otherwise }(\%)\end{array}$ & 78 & & & \\
\hline Annual labor (off farm) income in ETB & 932.07 & 2803.61 & 0 & 20000 \\
\hline Distance to the nearest main road in kilometer & 4.06 & 5.20 & .012 & 16.26 \\
\hline Distance to the forest (core areas) in kilometer & 2.52 & 1.20 & 0.91 & 6.13 \\
\hline District dummy (1 if household is living in Yayu) (\%) & 72 & & & \\
\hline
\end{tabular}

Two sets of indicators for location, distance from the core forest areas and distance from the main road, were included in the empirical analysis. ${ }^{9}$ Location from the forest is considered to be one of the most important factors in determining where and how much to collect and it is hypothesized to be inversely related with the forest income (Belcher et al. 2015; Robinson 2016). Several studies show that households who are far from forests are less dependent on forest and forest resources than those who are relatively close (Kamanga et al. 2009; Robinson 2016). We also examine the effect of the location of households from the main road in the total value of NTFPs collected as well as on their level of dependency on forest resources.

Empirical studies have also shown that lack of access to credit or liquidity-constrained households tend to depend more on forests and forest resources compared to other activities (Swinton and Quiroz 2003; Babulo et al. 2008). The household was asked whether he/she believes that he/she has access to credit or not from formal or informal institutions. The descriptive statistics shows that $70 \%$ of the sampled respondents believe they have access to either formal or 
informal credit. Since more than $78 \%$ of the sampled households reported that coffee growing is the most important activity, access to credit would enable them to buy the necessary inputs in order to enhance production and productivity of the main crop. We have included labor income (off farm income), which consists of income from participation in off farm activities such as coffee farm, crop production, construction sector and mining. Though there is significant variation among the participants, on average, sample households get birr 932 per annum from labor income. We expect that labor income from other sources reduces household's dependency on forest resources.

The number of adult members, other than the head, in the household and presence of children are included in the empirical analysis. On average, a household has 1.17 adult members other than the head with a minimum of 0 and maximum of 16. More labour may mean more demand for labour outside forest resources. The presence of children under five in the family is a binary variable represented as one if there is a child whose age is less than 5 and zero if not. Presence of children in the household is expected to reduce use of forest resources as children compete with other activities for adults' time.

In addition the health status of the household is measured as a binary variable and denoted as 1 if poor health frequently affects the household, and 0 otherwise. About $38 \%$ of the sampled households reported that they have been affected by poor health. We expect that households with poor health condition are more likely to collect NTFPs and more dependent on forest resources.

\subsection{NTFPs and local livelihoods}

We have also assessed the role of forest products in generating cash for households living in the study areas. Just over one third of the sampled households receive cash income from annual crop farming and around one fifth from growing/selling chat. ${ }^{10}$ About two-fifths derive cash income by participating in the labor market, including coffee farming, crop production, construction and

mining. Figure 2 provides information on the proportion of households that obtained cash income from various activities. 


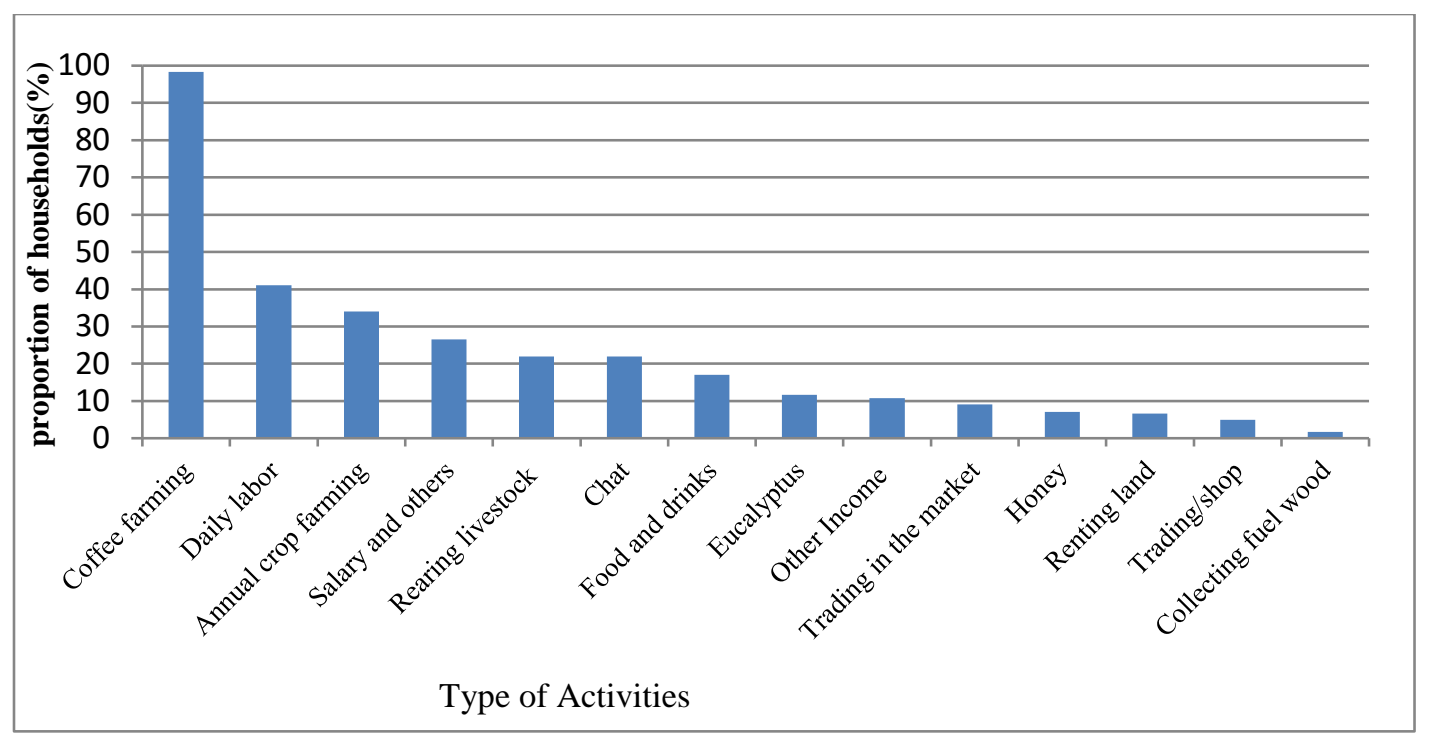

Figure 2: Proportion of households obtained cash income from various sources

Unlike the findings of other similar studies (see for example, Cavendish 2000; Mahapatra et al. 2005; Tesfaye et al. 2010) NTFPs, including firewood, have a small contribution to the total cash income of households in our study areas. This suggests that people in our study site use NTFPs mainly for home consumption, relying primarily on the sale of coffee for cash income. A similar study by Kamanga et al. (2009) also found that forest resources are less important as a source of cash income for all categories of households in Malawi and most of the forest products are consumed directly.

Figure 3 provides information on the number of households that collect each forest product. The result shows that fuel wood is the forest product collected by most households (more than 93\%), followed by liana (59\%). ${ }^{11}$ People use liana for fencing and other construction activities such as housing maintenance. Other NTFPs such as medicinal plants, spices, wild coffee seedlings and fodder are collected by a relatively small proportion of households. 


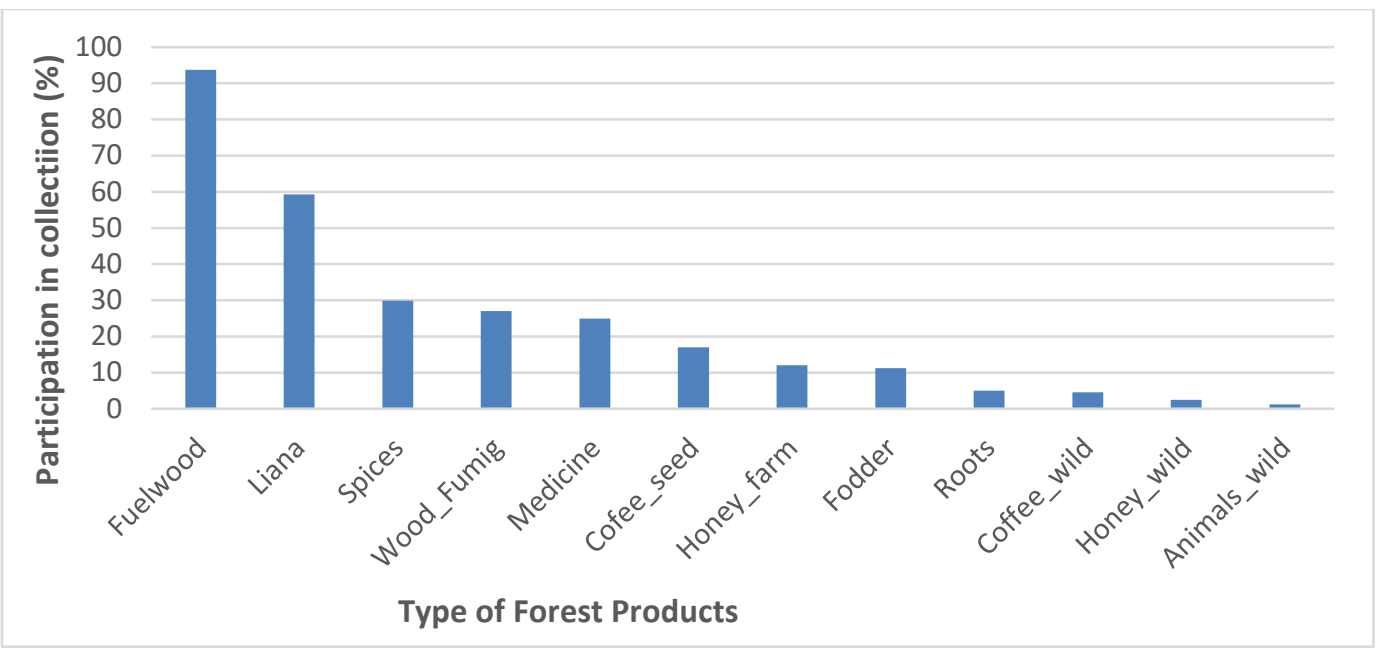

Figure 3: Level of participation of households in collection of forest products

Participation in collection of coffee from the forest (wild coffee) is limited to only $4.6 \%$ of sample households. However, considerably more households collect coffee seedlings from the forest. Since households in the study area are highly dependent on coffee, then collecting coffee seedlings from the natural forest is important as an input to the main cash crop, cultivated coffee.

Table 2 shows the annual mean values of NTFPs which are calculated for all households included in the survey. Firewood is the most important forest product in terms of value. Wild coffee and honey are the second and third most important forest products in terms of value, respectively, though not many people participate in the collection of these products. On the other hand, forest products such as liana are collected by most households but have a low value which might be due to the easy availability of such products. The value of forest products collected varies between the two sample sites (Table 2). For example, the average value of spices and honey collected in Doreni district is higher than that of Yayu district and the differences are statistically significant. However, the total value of NTFPs collected in Yayu district is higher than Doreni district, though the difference is not statistically significant. 
Table 2: Summary of value (in Birr) ${ }^{1}$ of selected forest products per household per annum

\begin{tabular}{|l|r|r|r|r|r|r|l|}
\hline \multirow{2}{*}{ Types of NTFPs } & \multicolumn{2}{|l|}{ YAYU (N=174) } & \multicolumn{2}{l|}{ (DORENI=67) } & \multicolumn{2}{l|}{ TOTAL (N=241) } & T-Test \\
\cline { 2 - 9 } & Mean & S. D. & Mean & S. D. & Mean & S. D. & $\begin{array}{l}\text { Mean(doreni) } \\
- \text { mean(yayu) }\end{array}$ \\
\hline Firewood & 3255 & 1913 & 2953 & 2027 & 3171 & 1946 & -302 \\
\hline Medicines & 459 & 1886 & 203 & 660 & 388 & 1642 & -256 \\
\hline Wild Coffee & 251 & 1639 & 136 & 842 & 219 & 1461 & -116 \\
\hline Honey & 111 & 421 & 372 & 900 & 184 & 604 & $261^{* * *}$ \\
\hline Spice & 112 & 338 & 247 & 527 & 149 & 403 & $135^{* * * *}$ \\
\hline Liana & 36 & 51 & 32 & 49 & 35 & 51 & -4 \\
\hline Fodder & 8 & 32 & 12 & 43 & 9 & 35 & 4 \\
\hline Other Ntfps & 12 & 36 & 47 & 131 & 22 & 77 & $35^{* * *}$ \\
\hline Total Value of NTFPs & 4246 & 3157 & 4002 & 2564 & 4178 & 3000 & -244 \\
\hline
\end{tabular}

${ }^{1}$ At the time of the survey, the exchange rate was 1 USD $\approx 20.33$ ETB. The last column (T-test) show that, on average, households in Dorenni district collect more honey and spices than households in Yayu. There are no statistically significant differences in collection of other types of forest products between households in the two districts.

Table 3 provides a summary of annual income and share of income derived from forest products derived by sampled households. The share of income derived from forests ranges from 4 to $26 \%$. The total value of NTFPs collected and the share of income derived from forests, the absolute and relative income, ${ }^{12}$ respectively, differ according to the socioeconomic status of households. Unlike the findings from much of the literature, there is no clear evidence that the relatively better off households (especially the top quintiles) collect more from the forest than the relatively poor (Table 3). A recent study by Dokken and Angelsen (2015) suggests that this relationship is dependent on the type of income used to categorize households, particularly whether predicted $^{13}$ or observed income is used. For example, if we consider predicted income then the better-off households do not use more forest products in an absolute sense. 
Table 3: Summary of annual income and share of income derived from forest products derived by sampled households (by quintile)

\begin{tabular}{|c|c|c|c|c|c|c|}
\hline \multicolumn{7}{|c|}{ Income Quintiles } \\
\hline \multirow[b]{2}{*}{ Types of NTFPs } & \multirow{2}{*}{$\begin{array}{c}1 \\
\text { (Lower 20\%) }\end{array}$} & 2 & 3 & 4 & \multirow{2}{*}{$\begin{array}{c}5 \\
\text { (Top } \\
20 \% \text { ) }\end{array}$} & \multirow[t]{2}{*}{ All } \\
\hline & & & & & & \\
\hline \multicolumn{7}{|c|}{ Total value of NTFPs } \\
\hline Value of NTFPs & 2976 & 4422 & 4590 & 4319 & 4702 & 4178 \\
\hline -Valueof firewood & 2586 & 3348 & 3551 & 3252 & 3176 & 3171 \\
\hline -Value of spice & 91 & 164 & 218 & 126 & 158 & 149 \\
\hline \multicolumn{7}{|c|}{ Share of income } \\
\hline Share of NTFPs & 0.26 & 0.19 & 0.13 & 0.08 & 0.04 & 0.15 \\
\hline -Share of firewood & 0.26 & 0.15 & 0.10 & 0.06 & 0.03 & 0.12 \\
\hline -Share of spice & 0.01 & 0.01 & 0.01 & 0.00 & 0.00 & 0.01 \\
\hline \multicolumn{7}{|c|}{ Other household wealth indicators } \\
\hline Livestock & 1.28 & 1.75 & 2.10 & 2.37 & 2.94 & 2.10 \\
\hline Coffee area (ha) & 0.52 & 0.73 & 0.95 & 1.58 & 2.24 & 1.19 \\
\hline Annual Expenditure & 8717 & 10076 & 10219 & 10549 & 14672 & 10826 \\
\hline Total Income & 11183 & 22530 & 35954 & 59914 & 126319 & 49966 \\
\hline
\end{tabular}

As expected, forest dependence (value of NTFPs as a share of total income) is negatively correlated with total income. The pairwise correlations also show that the correlation coefficient is -0.33 which is statistically significant at $1 \%$ level (Appendix A). For example, forest dependence among the poorest $20 \%$ (where forest dependence is 26\%) is almost seven times higher than for the top 20\%(where forest dependence is less than 4\%). In line with much of the literature (see for example, Kamanga et al. 2009; Heubach et al. 2011; Kar and Jacobson, 2012) our result implies that NTFPs are particularly important for the poorest households. On the other hand, in contrast to most empirical studies (e.g. Cavendish 2000; Cordova et al. 2013), we found no clear pattern regarding the relationship between total income and total value of NTFPs collected. However, as shown in Table 3, the value of NTFPs collected by people in the lowest income quintile is lower than for the other income quintiles and the differences are statistically significant. 


\subsection{Determinants of absolute forest income and forest dependency}

In this section, we present the results of empirical estimation and discuss the results. We focus our discussion and interpretations based on the findings of the total (aggregate) estimations.

Table 4 and 5 show estimation results from the Tobit model. This allows us to explore the various factors affecting the gross value of NTFPs collected and forest dependency, respectively. In both tables, the first column shows the estimation results for all NTFPs combined (aggregate value of NTFPs and share of NTFP). We have also estimated OLS for the NTFPs as the number of zeros is very small. The results are similar. The remaining columns present results separately for firewood, liana and spices. We have not estimated separate regressions for other NTFPs such as medicinal plants, wild coffee, and honey, because each is collected by a small proportion of the sampled households (see Figure 2). A number of variables are revealed to be important and significant determinants of forest dependency. ${ }^{14}$ 
Table 4: Determinants of gross value of NTFPs collected

\begin{tabular}{|c|c|c|c|c|}
\hline Variables & NTFPs & Fuel & Liana & Spice \\
\hline \multirow[t]{2}{*}{ Age of respondent } & -0.008 & -0.014 & -0.011 & 0.045 \\
\hline & $(0.008)$ & $(0.010)$ & $(0.017)$ & $(0.040)$ \\
\hline \multirow[t]{2}{*}{ Respondent is male } & $-0.743 * *$ & $-0.743^{* *}$ & 1.080 & 0.136 \\
\hline & $(0.312)$ & $(0.335)$ & $(0.798)$ & $(1.913)$ \\
\hline \multirow[t]{2}{*}{ Respondent is married } & $0.719 * *$ & $0.717 * *$ & -0.682 & -0.629 \\
\hline & $(0.312)$ & $(0.341)$ & $(0.658)$ & $(1.773)$ \\
\hline \multirow[t]{2}{*}{ Education of Respondent } & -0.025 & -0.030 & -0.019 & 0.140 \\
\hline & $(0.041)$ & $(0.043)$ & $(0.061)$ & $(0.161)$ \\
\hline \multirow{2}{*}{ Presence of children } & $-0.462 *$ & -0.453 & 0.184 & 0.875 \\
\hline & $(0.252)$ & $(0.294)$ & $(0.443)$ & $(1.124)$ \\
\hline \multirow[t]{2}{*}{ Coffee area } & 0.141 & 0.191 & $1.045^{* *}$ & $2.734 * *$ \\
\hline & $(0.252)$ & $(0.323)$ & $(0.476)$ & $(1.146)$ \\
\hline \multirow[t]{2}{*}{ Livestock in TLU } & 0.088 & -0.072 & $0.551 *$ & 0.518 \\
\hline & $(0.178)$ & $(0.202)$ & $(0.320)$ & $(0.791)$ \\
\hline \multirow[t]{2}{*}{ Distance main road } & -0.051 & 0.005 & -0.104 & $-0.630 * *$ \\
\hline & $(0.054)$ & $(0.070)$ & $(0.118)$ & $(0.280)$ \\
\hline \multirow[t]{2}{*}{ Monthly Expenditure } & $-0.531 * *$ & $-0.515^{* *}$ & $-1.283 * * *$ & $-2.319 * * *$ \\
\hline & $(0.223)$ & $(0.252)$ & $(0.293)$ & $(0.710)$ \\
\hline \multirow[t]{2}{*}{ Household living in Yayu } & -0.305 & 0.479 & -0.959 & $-9.807 * * *$ \\
\hline & $(0.569)$ & $(0.774)$ & $(1.302)$ & $(3.079)$ \\
\hline \multirow[t]{2}{*}{ Main activity coffee farming } & 0.446 & 0.151 & 0.526 & $3.375^{* *}$ \\
\hline & $(0.319)$ & $(0.348)$ & $(0.533)$ & $(1.350)$ \\
\hline \multirow[t]{2}{*}{ Number of adults } & -0.016 & 0.018 & -0.192 & -0.185 \\
\hline & $(0.064)$ & $(0.073)$ & $(0.144)$ & $(0.345)$ \\
\hline \multirow[t]{2}{*}{ Access to credit } & $0.534 *$ & $0.675^{*}$ & 0.734 & -0.954 \\
\hline & $(0.321)$ & $(0.365)$ & $(0.473)$ & $(1.140)$ \\
\hline \multirow[t]{2}{*}{ Health condition } & $0.365 * *$ & $0.445^{* *}$ & 0.668 & $1.719 *$ \\
\hline & $(0.179)$ & $(0.220)$ & $(0.423)$ & $(1.039)$ \\
\hline \multirow[t]{2}{*}{ Distance to forest } & -0.063 & $-0.255^{*}$ & $0.645^{* * *}$ & $1.614 * * *$ \\
\hline & $(0.099)$ & $(0.138)$ & $(0.167)$ & $(0.416)$ \\
\hline \multirow[t]{2}{*}{ Constant } & $11.479 * * *$ & $11.147 * * *$ & $7.195 * * *$ & 10.135 \\
\hline & $(1.877)$ & $(2.119)$ & $(2.599)$ & $(6.148)$ \\
\hline \multirow[t]{2}{*}{ Sigma } & $1.775 * * *$ & $2.075 * * *$ & $2.866^{* * *}$ & $6.118 * * *$ \\
\hline & $(0.212)$ & $(0.224)$ & $(0.168)$ & $(0.392)$ \\
\hline Log likelihood & 477.09 & -511.51 & -420.19 & -299.96 \\
\hline Observations (N) & 241 & 241 & 241 & 241 \\
\hline
\end{tabular}

*The variables livestock, coffee area, and monthly expenditure are all in logarithmic form. Superscripts $* * *$, and $* * *$ denote significance at the $10 \%, 5 \%$, and $1 \%$ level, respectively. The numbers shown in parenthesis are robust standard errors. $\mathrm{N}$ refers to the number of observations. 
Table 5: Determinants of dependence on non-timber forest products

\begin{tabular}{|c|c|c|c|c|}
\hline Variables & Share_NTFP & S_Fuel & S_Liana & S_Spice \\
\hline \multirow[t]{2}{*}{ Age of respondent } & 0.000 & -0.000 & -0.000 & $0.001 *$ \\
\hline & $(0.001)$ & $(0.000)$ & $(0.000)$ & $(0.000)$ \\
\hline \multirow[t]{2}{*}{ Respondent is male } & -0.021 & 0.002 & 0.001 & 0.002 \\
\hline & $(0.030)$ & $(0.023)$ & $(0.001)$ & $(0.010)$ \\
\hline \multirow[t]{2}{*}{ Respondent is married } & 0.006 & 0.001 & -0.001 & -0.005 \\
\hline & $(0.027)$ & $(0.022)$ & $(0.001)$ & $(0.010)$ \\
\hline \multirow[t]{2}{*}{ Education of Respondent } & -0.001 & -0.003 & -0.000 & 0.001 \\
\hline & $(0.002)$ & $(0.002)$ & $(0.000)$ & $(0.001)$ \\
\hline \multirow{2}{*}{ Presence of children } & $-0.042 * * *$ & $-0.037 * *$ & 0.000 & 0.004 \\
\hline & $(0.016)$ & $(0.015)$ & $(0.000)$ & $(0.006)$ \\
\hline \multirow[t]{2}{*}{ Coffee area } & $-0.107 * * *$ & $-0.090 * * *$ & -0.001 & 0.004 \\
\hline & $(0.023)$ & $(0.022)$ & $(0.001)$ & $(0.006)$ \\
\hline \multirow[t]{2}{*}{ Livestock in TLU } & 0.010 & 0.005 & -0.000 & 0.003 \\
\hline & $(0.012)$ & $(0.010)$ & $(0.000)$ & $(0.004)$ \\
\hline \multirow[t]{2}{*}{ Distance main road } & -0.006 & -0.004 & -0.000 & $-0.003 *$ \\
\hline & $(0.004)$ & $(0.003)$ & $(0.000)$ & $(0.002)$ \\
\hline \multirow[t]{2}{*}{ Monthly Expenditure } & $-0.024 * *$ & -0.012 & $-0.001 * * *$ & $-0.014 * * *$ \\
\hline & $(0.010)$ & $(0.009)$ & $(0.000)$ & $(0.005)$ \\
\hline \multirow[t]{2}{*}{ Household living in Yayu } & $-0.091 * *$ & -0.055 & -0.002 & $-0.051 * * *$ \\
\hline & $(0.043)$ & $(0.035)$ & $(0.002)$ & $(0.018)$ \\
\hline \multirow[t]{2}{*}{ Main activity is coffee farming } & 0.011 & -0.014 & $0.001^{*}$ & $0.019 * * *$ \\
\hline & $(0.022)$ & $(0.020)$ & $(0.001)$ & $(0.007)$ \\
\hline \multirow[t]{2}{*}{ Number of adults } & -0.007 & -0.004 & -0.000 & -0.002 \\
\hline & $(0.004)$ & $(0.004)$ & $(0.000)$ & $(0.002)$ \\
\hline \multirow[t]{2}{*}{ Access to credit } & -0.008 & 0.004 & 0.001 & -0.003 \\
\hline & $(0.020)$ & $(0.018)$ & $(0.000)$ & $(0.006)$ \\
\hline \multirow[t]{2}{*}{ Health condition } & 0.010 & 0.018 & 0.001 & 0.009 \\
\hline & $(0.017)$ & $(0.014)$ & $(0.000)$ & $(0.006)$ \\
\hline \multirow[t]{2}{*}{ Annual Labour income } & 0.004 & $0.005^{* *}$ & $-0.000 * *$ & 0.001 \\
\hline & $(0.003)$ & $(0.003)$ & $(0.000)$ & $(0.001)$ \\
\hline \multirow[t]{2}{*}{ Distance to forest } & -0.001 & -0.008 & $0.001^{* *}$ & $0.008 * * *$ \\
\hline & $(0.007)$ & $(0.006)$ & $(0.000)$ & $(0.002)$ \\
\hline \multirow[t]{2}{*}{ Constant } & $0.472 * * *$ & $0.362 * * *$ & $0.008 * * *$ & 0.050 \\
\hline & $(0.095)$ & $(0.085)$ & $(0.003)$ & $(0.033)$ \\
\hline \multirow{2}{*}{ Sigma } & $0.121 * * *$ & $0.106^{* * *}$ & $0.003 * * *$ & $0.032 * * *$ \\
\hline & $(0.011)$ & $(0.010)$ & $(0.000)$ & $(0.005)$ \\
\hline Log likelihood & 148.71 & 167.48 & 532.39 & 76.93 \\
\hline Observations $(\mathrm{N})$ & 236 & 236 & 236 & 236 \\
\hline
\end{tabular}

Note: *The variables livestock, coffee area, and monthly expenditure are all in logarithmic form.

Superscripts *, **, and $* * *$ denote significance at the $10 \%, 5 \%$, and $1 \%$ level, respectively. The numbers shown in parenthesis are robust standard errors. $\mathrm{N}$ refers to the number of observations. 
Among the explanatory variables, the presence of children under five in the family is negatively and significantly related with both the value of NTFPs collected and forest dependency. This is expected as taking care of children requires more of family time and that would reduce time spent for collection of forest products. Quang and Anh (2006) also found that households who have higher dependency ratio do not benefit as much from collection of NTFPs because they lack spare labor. The value of NTFPs is higher for married respondents. On the other hand, households with male respondents collect less amount of NTFPs. ${ }^{15}$ In line with the literature, our finding regarding the sign and significance of gender in our analysis is expected. This might be due to the nature of NTFP activities which are attractive because of the low technical and financial entry requirements, for what is a freely available resource base (IFAD, 2008). Households with more adult members are less dependent on forests but there is no significant effect for absolute forest income. This may be due to the tendency of adult members of the household to undertake non-forest off farm activities or to undertake the main farming activities (crop and coffee farming) in the study areas.

Contrary to the findings of some empirical studies (e.g. Belcher et al. 2015), we find that there is no significant relationship between total value of NTFPs collected and location of the household both from the core forest areas and the nearest main road. ${ }^{16}$ The lack of any significant relationships in our analysis is to be expected. First, we are studying a landscape in which there is no clear distinction between agriculture and forest. Specifically, coffee farming occurs in a semiforested buffer zone and households can collect many forest resources from their own land and common buffer zone areas. Moreover, the core zones are highly protected and little resource extraction occurs there. Second, in our sample there are very few sales of NTFPs. This may be because most households get cash income from coffee.

Household wealth indicators such as land size, livestock holding and monthly expenditure were included to explore the relationship between forest resource use and wealth. Households' monthly expenditure is negatively and significantly related to NTFP income for all the regressions. This suggests that the better off households are less dependent on forest resources in absolute terms. This again differs from the findings of much of the related literature which finds that relatively rich households use more forest resources but these resources are a smaller share of their total income, compared to relatively poor households (Cavendish 2000; Vedeld et al. 
2007).However, monthly expenditure is negatively correlated with NTFP dependency and the results are significant except for fuelwood (Table 5). This suggests that the relatively poor households are more dependent on NTFPs than wealthier households. Figure 4 also shows the negative relationship between forest dependence and total income of households in the study sites. This figure shows that NTFP income constitutes a larger share of total household income (up to $80 \%$ ) in poorer households compared to the less-poor households. A plethora of empirical studies also find similar results in that poor households depend relatively more on NTFPs, though the extent of dependency varies based on socioeconomic, geographical and environmental characteristics of the study area. For example, Quang and Anh (2006) in Vietnam, Kar and Jacobson (2012) in Bangladesh and Asfaw et al. (2013) in Ethiopia find that the poor are more dependent on NTFPs than the wealthier households. Contrary to these findings, Adhikari (2005) found that the poor are less dependent on forests than the rich in Nepal.

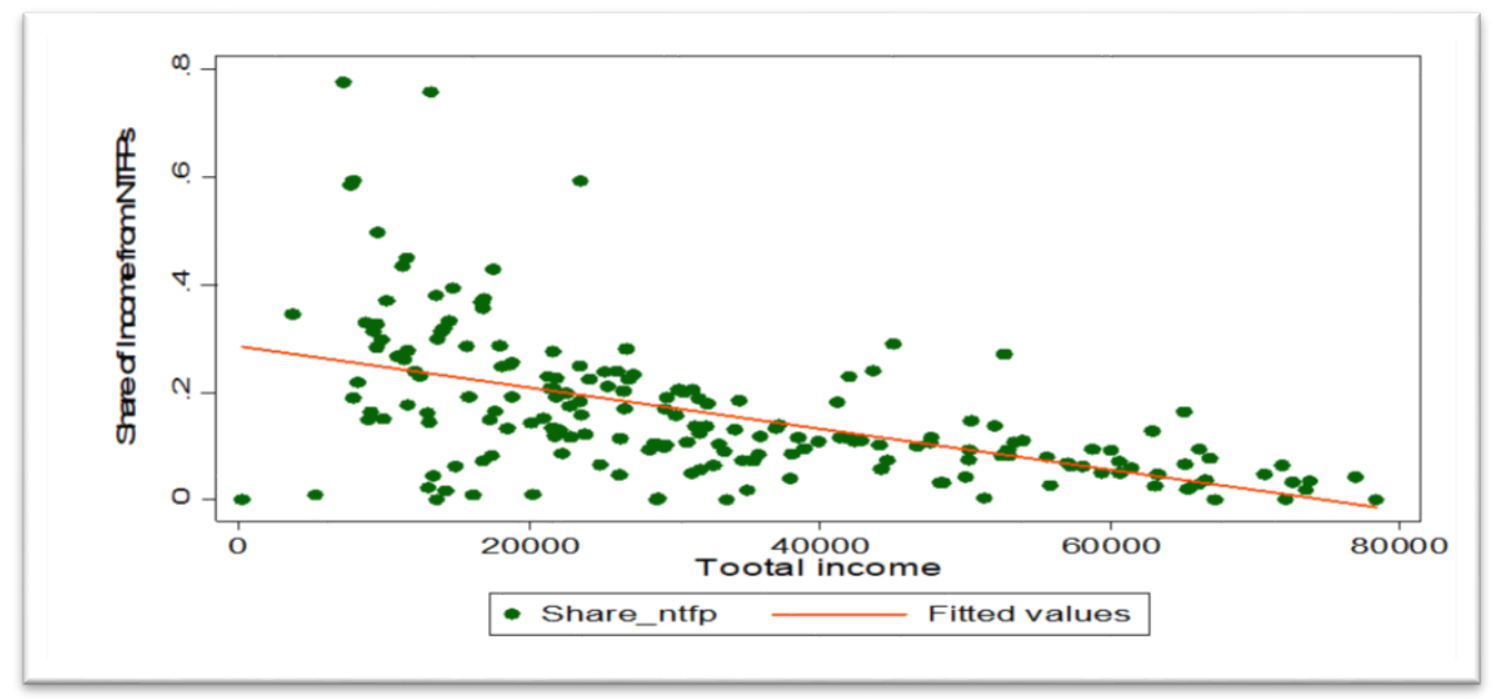

Figure 4. Relationship between shares of income derived from NTFPs and total income 


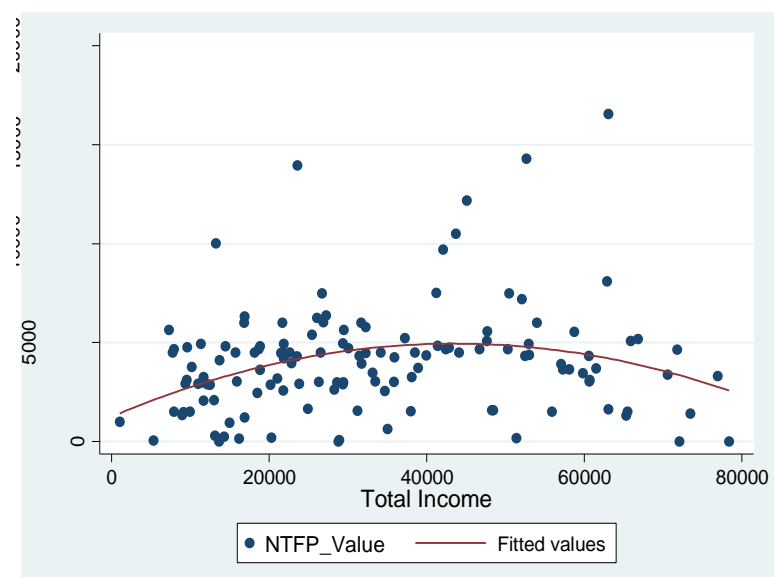

(a) Yayu district

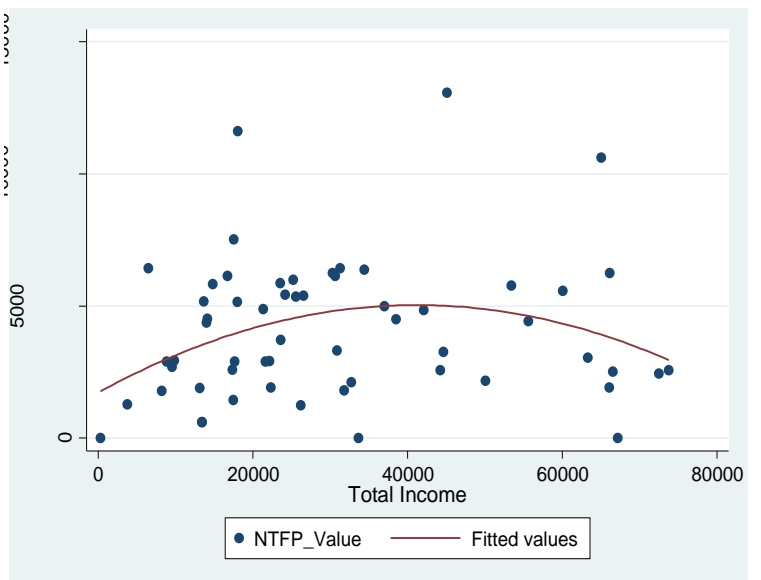

(b) Doreni district

Figure 5: Relationship between total income and total value of NTFPs collected

The findings show that use of forest resources in the study area is correlated with different indicators of wealth but the sign and significance depends on the type of wealth indicators and the type of NTFP considered in the analysis. Households' economic status as proxied by land holding for coffee farming is negatively correlated with dependency on forests. The negative sign for land holding for coffee indicates that households with large land size for coffee growing purpose are less dependent on NTFPs. A simple descriptive shows that those with large land size produce more coffee which is the main crop in the study area. So these households are using either their own land for forest products or do not need the forest products for their livelihoods, whether for subsistence or cash income. Our finding is consistent with similar studies that show land size is negatively correlated with forest dependence (Fisher 2004; Quang and Anh 2006). ${ }^{17}$

Unexpectedly, other factors such as the effect of credit are positively and significantly correlated with NTFP collection. Households with poor health condition are more likely to collect NTFPs. This might be due to the nature of other activities such as farming in rural areas which are laborious and hard. So less healthy people might depend more on the relatively free resources which are also easy to collect. Forest resources are also found in the literature to be an important safety net, which would also fit with this observation.

Unlike the findings of other similar studies (see for example, Mamo et al. 2007) labor income from other sources does not seem to reduce households' dependency on forests. However, 
labor income is positively correlated with dependency on fuel wood. The explanation for this result could be that people might be collecting firewood on their way to/from work and therefore might have more opportunity to collect it than lianas which would require a special trip.

Finally, in order to account for the effect of geographical and other district level factors not accounted in the regression, we included a district dummy in the regression. We find that there is no significant difference in the total value of NTFPs collected between the two districts. However, households living in Yayu district are less dependent than those in Doreni on NTFPs in general and on spices, which are collected from both own land and forest. This suggests that interaction between households and forest resource use varies from region to region and hence is site specific. One cannot generalize the nexus to all socioeconomic groups and all regions (Kar and Jacobson 2012).

In sum, this study finds that location, presence of children less than five years old, number of adults, household's monthly expenditure, and size of coffee area are important determinants of household dependence on NTFPs. The finding is in line with the conventional findings that the relatively poor are more dependent on forests than the relatively better off households. Therefore, the relevant stakeholders in YCFBR should take in to consideration the importance of forest resources for the relatively poor rural households when planning interventions aiming to improve the livelihood of the people as well as in protection of the YCFBR.

\section{Conclusion and policy implications}

Households living in and around the YCFBR in Ethiopia, like most households that live within a forest landscape, allocate their time across a number of different activities, including farming, wage labor, and the collection of NTFPs. Our research, in common with much of the literature, finds that poor households in particular rely on NTFPs for a relatively large share of their total income. However, unlike much of the literature, households in our sample rarely sell NTFPs, but rather collect almost exclusively for their home use. Moreover, our findings are also somewhat unusual in as much as NTFPs do not contribute more in absolute terms to wealthier households' income than to less wealthy households. A central reason for these findings may be that all households in the survey have access to land to grow crops, and the main crop cultivated by households, coffee, is grown under semi-shade conditions. This means that all households have 
access to cash income from farming, and typically households have access to forest products from their own land.

The strict zoning of the YCFBR into core, buffer, and transitional areas, may have ensured that NTFPs are available in the buffer zone, and thus households do not need to go into the protected core to collect resources (Albers 2010; Robinson et al. 2013). A further consequence is likely to be that, if households are collecting NTFPs from their own forested land, they are more likely to collect these resources sustainably, thus avoiding the potential "tragedy of the commons" when households rely on the commons for forest resources.

Our findings suggest that in our case study site, most NTFP extraction is to fulfill a regular need for fuelwood, with collection of other resources also closely linked to supporting current consumption. We also found little evidence of households selling NTFPs and thus little potential for NTFPs to provide a pathway out of poverty. However, one can argue that in the Yayu forest landscape, cultivated coffee provides environmental income, given that it is grown in semiforested conditions, that some of the coffee plants are from the broader landscape, and that the core can be a source of new planting material when more pest and disease-resilient plants are sought.

We find that use of forest resources are influenced by several socioeconomic, village and other characteristics. Variables included in the empirical analysis show that some of the determinants of forest dependency and total annual forest income are different. In this study, we find that female headed households tend to collect more NTFP than male headed households, showing that interventions aiming to restrict access to forest resources in our study area may affect the livelihood of the rural people particularly rural women. Forests are also found to be an important source of income for the less healthy people in the study areas. Location also matters as people living near to towns or areas with relatively access to infrastructure are less dependent on forest resources.

Looking to the future, the benefits that households gain from living and farming within a forest landscape may be compromised. This is a consequence of the continuous deterioration of forests and forest resources due to expansion of land for agriculture resulting from population pressure, increasing demand for fuel wood, illegal logging, and forest fires (FDRE 2011). 
Population growth, poor law enforcement, land tenure insecurity, and lack of sufficient off-farm work opportunities, are all underlying causes (MEFCC 2016). The approach taken in the YCFBR, whereby the forest buffer zone provides an important source of cash income through the cultivation of shade coffee offers important lessons for forest conservation and livelihood enhancement elsewhere. That is, this approach can be adopted in other similar areas as YCFBR can be a good example for enhancing the livelihood of the people surrounding the forests as well as conservation of the biosphere (Woldegeorgis and Wube, 2012). Future studies on the role of forests may also focus on examining the role of forests as safety nets.

\section{Acknowledgements}

The authors gratefully acknowledge the grant obtained from the Ecosystem Services for Poverty Alleviation (ESPA) programme, funded by the Department for International Development (DFID), the Economic and Social Research Council (ESRC) and the Natural Environment Research Council (NERC).

\section{Disclosure statement}

No potential conflict of interest was reported by the authors. 
Notes

${ }^{1}$ Note that different terms are used in the literature as synonyms for non-timber forest products. Various authors used terms such as minor forest products, non-wood forest products, and secondary forest products interchangeably. In this paper, the term NTFPs is used to refer to all types of forest products except timber and includes firewood and other non-wood forest products such as spices, medicinal plants, fodder, etc.

${ }^{2}$ For example, if two individuals with the same total level of household incomes derive equal amounts of forest resources which have equal value, then according to the definition of forest dependency (i.e., the ratio of forest resources to total household income, the ratio will be higher for the poor.

${ }^{3}$ Retrieved from http://www.unesco.org/new/en/natural-sciences/environment/ecological-sciences/biospherereserves/africa/ethiopia/yayu/.

${ }^{4}$ It is believed that the historical value of this site to the community has contributed to its preservation.The local inhabitants in the study area are ethnic Oromos. The Gadaa System organizes the Oromo society in to groups or sets (about 7 to 11) that assume different responsibilities and society every eight years. The historical Gada Assembly site, known as Bakke-Abba-Alanga(literally means Lawmakers or Legislators Site) is located in the southern part of the proposed biosphere reserve area. All customary rules and amendments to the existing rules of the indigenous institutions used to be made at Bakke-Abba-Alanga.

${ }^{5}$ Kebele is the lowest administrative unit in Ethiopia

${ }^{6}$ Alternatively, it is possible to use the local price as reported by farmers (what they receive to sell a unit of that particular product) to value the total amount of forest products collected in a year.

${ }^{7}$ The contribution of forests to major environmental services such as soil conservation and carbon sequestration, or general aesthetic and spiritual values is not considered in this study. Such services require specialized valuation techniques, such as contingent valuation, travel costs methods, etc (Cavendish 2002). In general, the values reflect the gross economic value of non-timber forest products. For this reason scholars agreed that NTFPs have often been undervalued since studies only considered their direct-use values (Shackleton et al. 2001).

${ }^{8}$ For detail discussion on Tobit models please refer to Scott (1997) and Maddala (1983)

${ }^{9}$ Since we do not have actual measurements for distance, it is calculated using GPS location of household and ArcGIS $3 \mathrm{D}$ analysis which accounts for slope. In addition, data on distance from the buffer zone (instead of core areas) would have been better as actual collection of NTFP takes place in this zone.

${ }^{10}$ Chat is an important perennial crop widely cultivated in the Ethiopian highlands of Oromia region.

${ }^{11}$ This is a long-stemmed, woody vine that is rooted in the soil and climbs or twines around other plants (retrieved fromhttps://en.wikipedia.org/wiki/Liana).They are used to make a variety of things including baskets, ropes and wicker furniture in the study area.

${ }^{12}$ In this study, absolute forest income is the total value of forest products collected (both consumption and cash income); relative forest income is the share of forest income to total household income; and forest dependency is defined as a case where people's subsistence livelihoods are in part derived from forests. That is, if some part of their own diet, housing, transport, fuel, or medicine comes from forests (Newton et al., 2016).

${ }^{13}$ According to Dokken and Angelsen (2015), the predicted income in the analysis of forest reliance in Tanzania is obtained from a regression of income on household assets(including liquid and non-liquid assets), household characteristics, and other village level variables in a regression. The authors argue that the resulting predicted income is a better measure for the poverty status of a household than the observed income.

${ }^{14} \mathrm{As}$ the number of zeros is few, we ran a multiple regression (OLS) model of the share of forest income against the same socio-economic variables. We found that the results are the same. This is due to the fact that the regression results using Ordinary Least Squares (OLS) converge to Tobit estimates as the number of zeros decreases.

${ }^{15}$ It has to be noted that the respondents are also the main decision makers in the household.

${ }^{16}$ However, a recent study by Angelsen etal.(2014) found that households located close to forests do not have significantly higher absolute or relative forest income. As discussed in section 3.1, we do not have household level information on location measured in terms of distance of households from forest and the nearest main road. Hence the result based on the GIS based information should be interpreted with caution.

${ }^{17}$ We have also included livestock ownership as an additional wealth indicator. We found that it is not significant, probably due to the nature of the farming system. In the study area livestock is less important and the local community livelihoods are primarily based on food crops and coffee production (Gole et al., 2014). 


\section{References}

Adhikari, B.2005."Poverty, Property Rights, and Collective Action: Understanding the Distributive Aspects of Common Property Resource Management."Environment and Development Economics 10 (1): 7-31.

Adhikari, B., Di Falco, S., and Lovett, J.C.2004."Household characteristics and forest dependency: Evidence from common property forest management in Nepal."Ecological Economics 48:245-257.

Albers, H.J.2010."Spatial modelling of extraction and enforcement in developing country protected areas."Resource and Energy Economics 32:165-179.

Angelsen, A., Jagger, P., Babigumira, R., Belcher, B., Hogarth, N., Bauch, S., Borner, J., Smithhall, C., and Wunder, S.2014."Environmental income and rural livelihoods: A global comparative analysis."World Development 64(S1): S12-S28.

Angelsen, A., Wunder, S. 2003. Exploring the Forest-Poverty Link: Key Concepts, Issues and Research Implications. CIFOR, Bogor, Indonesia. pp. viii, 58p.

Arnold, J.E.M. and Ruiz-Pérez, M. 2001. "Can Non-Timber Forest Products Match Tropical Forest Conservation and Development Objectives?"Ecological Economics 39: 437-447.

Asfaw, A., Lemenih, M., Kassa, H., Ewnetu, Z. 2013. "Importance, determinants and gender dimensions of forest income in eastern highlands of Ethiopia: The case of communities around Jelo Afromontane forest."Forest Policy and Economics 28:1-7.

Babulo, B., Muys, B., Nega, F., Tollens, E., Nyssen, J., Deckers,J., Mathijs, E.2008. "Household livelihood strategies and forest dependence in the highlands of Tigray, Northern Ethiopia."Agricultural Systems 98: 147-155.

Babulo, B., Bart, M., Fredu, N., Tollens, E., Nyssen, J., Deckers, J., Mathijs, E. 2009. “The economic contribution of forest resource use to rural livelihoods in Tigray, Northern Ethiopia."Forest Policy and Economics 11: 109-117.

Belcher, B., Achdiawan, R., and Dewi, S.2015. "Forest-Based Livelihoods Strategies Conditioned by Market Remoteness and Forest Proximity in Jharkhand, India." World Development 66: 269-279.

Beyene, D.L. 2014. "Assessing the impact of UNESCO biosphere reserves on forest cover change: the case of Yayu Coffee Forest Biosphere Reserve in Ethiopia." Unpublished MSc thesis, Wageningen University, Geo-information Science and Remote Sensing

Beyene, A.D. and S. F. Koch. 2011. "Non-Timber Forest Products Dependence, Property Rights and Local Level Institutions: Empirical Evidence from Ethiopia."Working Paper:2011-11.

Byron, N., Arnold, M. 1999. "What futures for the people of the tropical forests?"World Development 27: 789-805.

Cavendish, W. 2000. "Empirical Regularities in the Poverty-Environment Relationship of Rural Households: Evidence from Zimbabwe." World Development Vol. 28(11): 1979-2003.

Cavendish, W.2002."Quantitative methods for estimating the economic value of resource use to rural households, in Campbell, B. M. and Luckert, M. (eds)Uncovering the Hidden Harvest: Valuation Methods for Woodland and Forest Resources, Earthscan, London.

CIFOR. 2008. "Thinking beyond the canopy."CIFOR Annual Report.

Cooke, P.A.1998."Intrahousehold labor allocation responses to environmental good scarcity."Economic Development and Cultural Change 46(4):807-830. 
Cordova, J.P.P., Wunder, S., Smith-Hall, C., Borner, J. 2013. "Rural Income and Forest Reliance in Highland Guatemala."Environmental Management 51:1034-1043.

Coulibaly-Lingani, P., Tigabu, M., Savadogo, P., Oden, P.C., and Ouadba. J. M., 2009. Determinants of access to forest products in southern Burkina Faso. Forest Policy and Economics 11:516-524.

Dash, M., Behera, B.,Rahut, D.B. 2016. "Determinants of household collection of non-timber forest products(NTFPs) and alternative livelihood activities in Similipal Tiger Reserve, India."Forest Policy and Economics 73: 215-228.

Dokken, T., Angelsen, A. 2015. "Forest reliance across poverty groups in Tanzania."Ecological Economics 117: 203-211.

FAO. 2010. “Global Forest Resource Assessment FAO 2010.’Forestry paper 163 UN Food and Agriculture Organization, Rome.

FAO. 2016. "State of the World's Forests 2016. Forests and agriculture: land-use challenges and opportunities.'Rome.

Federal Democratic Republic of Ethiopia (FDRE). 2011. "Ethiopia's Climate-Resilient Green Economy: Green Economy Strategy." Addis Ababa, Ethiopia.

Fisher, M. 2004. "Household Welfare and Forest Dependence in Southern Malawi."Environment and Development Economics 9 (2): 135-54.

Gole, T.W., Senbeta, F., Tesfaye, K., \& Getaneh, F. 2009. "Yayu Coffee Forest Biosphere Reserve Nomination Form."Government of the Federal Democratic Republic of Ethiopia, Addis Ababa.

Gole, T.W., Ilfata, F.G., Tafa, M., and Aregachew, A. 2014. The Marginalized and Poorest in Different Communities and Settings of Ethiopia, in von Braun, J., Gatzweiler, J., F.W. (eds), Marginality: Addressing the Nexus of Poverty, Exclusion and Ecology, reference springer dordrechtheidelberg NewYork London, pp.365-381.

Heubach, K., Wittig,R., Nuppenau, E.A., Hahn, K. 2011. "The economic importance of non-timber forest products (NTFPs) for livelihood maintenance of rural West African communities: A case study from northern Benin.”Ecological Economics 70: 1991-2001.

IFAD. 2008. "Gender and non-timber forest products promoting food security and economic empowerment." Retrieved from http://www.ifad.org/gender/index.htm

Kamanga, P., Vedeld, P., Sjaastad, E. 2009. "Forest incomes and rural livelihoods in Chirad zulu District, Malawi." Ecological Economics 86(3):613-624.

Kar, S.P., Jacobson, M.G. 2012. "NTFP income contribution to household economy and related socio-economic factors: lessons from Bangladesh." Forest Policy and Economics 14:13642.

Maddala, G. S. 1983. Limited-Dependent and Qualitative Variables in Economics, New York: Cambridge University Press.

Mahapatra, A. K, Albers, H. J, Robinson, E.J. 2005. "The impact of NTFP sales on rural households' cash income in India's dry deciduous forest.'Environmental Management 35(3):258-65.

Mamo, G., Sjaastad, E., Vedeld, P. 2007. "Economic dependence on forest resources: A case from Dendi District, Ethiopia."Forest Policy and Economics 9(8): 916-927.

Ministry of Environment, Forest and Climate Change (MEFCC). 2016. "Study of causes of deforestation and forest degradation in Ethiopia and the identification and prioritization of strategic options to address those." Final report. 
Narain, U., Gupta, S., van'tVeld, K. 2008. "Poverty and resource dependence in rural India."Ecological Economics 66: 161-176.

Neumann, R.P., and Hirsch, E. 2000. "Commercialization of non-timber forest products: review and analysis of research." Center for International Forestry Research, Bogor, Indonesia.

Newton, P., Miller, D.C., Byenky, M.A.A., Arun Agrawal, A. 2016. "Who are forest-dependent people? A taxonomy to aid livelihood and land use decision-making in forested regions."Land use policy 57: 388-395.

Pattanayak, K., Sill, E.O.2001. "Do Tropical Forests Provide Natural Insurance? The Microeconomics of Non-Timber Forest Product Collection in the Brazilian Amazon."Land Economics Vol. 77(4): 595-612.

Quang, D.V., Anh, T. A. 2006. "Commercial collection of NTFPs and households living in or near the forests: Case study in Que, Con Cuong and Ma, Tuong Duong, NgheAn, Vietnam."Ecological Economics 60: 65-74.

Reddy, S., and Chakravarty, S. 1999. "Forest dependence and income distribution in a subsistence economy: evidence from India."World Development 27: 1141-1149.

Robinson, E. J. Z.2016. "Resource-dependent livelihoods and the natural resource base."Annual Review of Resource Economics 8 (1): 1941-1340.

Robinson, E.J.Z., Albers, H. J., Busby, G.M. 2013. "The impact of buffer zone size and management on illegal extraction, park protection, and enforcement." Ecological Economics 92: 96-103.

Scott L. J. 1997. Regression Models for Categorical and Limited Dependent Variables. Thousand Oaks, CA: Sage.

Shackleton C.M., Shackelton, S.E., \& Cousins B. 2001. "The role of land-based strategies in rural livelihoods: the contribution of arable production, animal husbandry and natural resource harvesting."Development Southern Africa 18:518-604.

Sills, E.O., Lele, S., Holmes, T.P., and Pattanayak, S.K. 2003. Nontimber Forest Products in the Rural Household Economy In: E.O. Sills and K.L. Abt (eds). Forests in a Market Economy. Kluwer Academic Publishers, Boston.

Swinton, S.M., Quiroz, R. 2003. "Is poverty to blame for soil, pasture and forest degradation in Peru's Altiplano?"World Development 31, 1903-1919.

Tesfaye, Y., Roos, A., Campbell, B., Bohlin, F. 2010. "Forest incomes and poverty alleviation under participatory forest management in the Bale Highlands, Southern Ethiopia."International Forestry Review 12 (1): 66-77.

Vedeld, P., Angelsen, A., Bojo, J., Sjaastad, E., and Berg, G. K.2007. "Forest environmental incomes and the rural poor."Forest Policy and Economics 9(7): 869-879.

White, H. 1980. "A Heteroskedasticity-Consistent Covariance Matrix Estimator and a Direct Test for Heteroskedasticity."Econometrica 48 (4): 817-38.

Woldegeorgis, G., and Wube, T. 2012. Survey on mammals of the Yayu forest in southwest Ethiopia. Short communication, SINET: Ethiop. J. Sci., 35(2):135-138.

Wunder, S. 2001. "Poverty Alleviations and Tropical Forests What Scope for synergies?" World Development 29 (11): 1817-1833. 
Appendix A.Pairwise correlation coefficient of selected variables

\begin{tabular}{|c|c|c|c|c|c|c|c|c|}
\hline & $\begin{array}{l}\text { Tot } \\
\text { Income }\end{array}$ & $\begin{array}{l}\text { NTFP } \\
\text { Value }\end{array}$ & $\begin{array}{l}\text { Share } \\
\text { ntfp }\end{array}$ & $\begin{array}{l}\text { Coffee } \\
\text { Area }\end{array}$ & Livestock & $\begin{array}{l}\text { Exp } \\
\text { month }\end{array}$ & $\begin{array}{l}\text { District } \\
\text { dum }\end{array}$ & $\begin{array}{l}\text { Labor } \\
\text { income }\end{array}$ \\
\hline Tot Income & 1 & & & & & & & \\
\hline NTFP Value & 0.004 & 1 & & & & & & \\
\hline Share ntfp & $-0.329 * * *$ & $\begin{array}{l}0.378 * * \\
*\end{array}$ & 1 & & & & & \\
\hline Coffee area & $0.341 * * *$ & 0.084 & $\begin{array}{l}- \\
0.322 * * *\end{array}$ & 1 & & & & \\
\hline Livestock & $0.273 * * *$ & 0.10 & $-0.113^{*}$ & $0.222 * * *$ & 1 & & & \\
\hline Exp_month & $0.318 * * *$ & -0.085 & $\begin{array}{l}- \\
0.181 * * *\end{array}$ & $0.138 * *$ & $0.120 *$ & 1 & & \\
\hline District_dum & 0.106 & 0.037 & -0.081 & -0.087 & $-0.300 * * *$ & $0.114 *$ & 1 & \\
\hline $\begin{array}{l}\text { Lbour } \\
\text { income }\end{array}$ & -0.099 & -0.027 & 0.103 & -0.089 & $-0.122^{*}$ & -0.015 & 0.072 & 1 \\
\hline
\end{tabular}

